\title{
Análisis semiótico de la publicidad española de brandy en la década de los cincuenta ${ }^{1}$
}

\section{SONIA MADRID CÁNOVAS}

CNRS-París

sonja@um.es

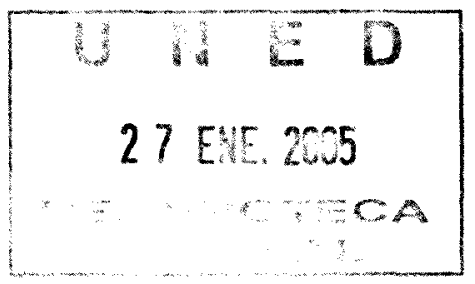

\section{INTRODUCCIÓN}

La publicidad como discurso social pluricodificado e hipercodificado se nos muestra, en apariencia pero voluntariamente, como un todo inasible, desorganizado y caótico sin otra finalidad que la consumición infinita de mensajes y productos, bienes o servicios por ella lastrados. Sin embargo, a nuestro juicio, el discurso publicitario posee unas estrategias muy concretas, aunque variadas, a lo largo de su historia puesto que tal promiscuidad codificativa es una manifestación abigarrada de una intensa puesta en discurso y una narratividad que dinamiza los itinerarios semánticos propios de cada época. De ahí que la metodología más adecuada para su estudio como discurso sea la metodología semiótica, entendida ésta como ciencia de la significación más que del significado, que actualmente cuenta con modelos operativos para abordar los problemas semióticos multimodales.

La metodología semiótica se ha "pre-ocupado» siempre de la búsqueda y ańlisis de los procedimientos significativos en el discurso publicitario, si bien estos interrogantes se han planteado desde diversas perspectivas y con muy distintas intenciones ${ }^{2}$. En los años sesenta la preocupación era de índole ideológica, puesto que se vislumbraba en el discurso publicitario un uso perverso de la

\footnotetext{
${ }^{1}$ Este trabajo ha sido realizado en el marco de un proyecto de investigación doctoral financiado por la Fundación Séneca.

${ }^{2}$ Para una revisión de los orígenes de la historia de la semiótica publicitaria, véase Victoroff (1972); Dyer (1982: 114-138); y Pérez Tomero (1982).
} 
retórica para instaurar una sociedad consumista, que anulaba la libertad de acción y pensamiento del individuo, creando modernas mitologías sociales mediante el signo. La semiótica se constituyo, entonces, como el arma más eficaz para desmontar, analizar y criticar tales discursos masivos y fascinantes. Barthes(1957 [1980], 1964, 1965 [1970]) fue uno de los pioneros ${ }^{3}$ en destacar la importancia de la connotación de los mensajes ${ }^{4}$ y se centró en la imagen porque ésta resultaba un medio relativamente novedoso de vehicular una información falsa, que se escondía en los pliegues del signo denotativo que suponía inicialmente toda fotografía. Él fue el primer semiótico que dirigió la mirada hacia la particular sintagmática de lo icónicoverbal, descubriendo que lo lingüístico existía en publicidad para acotar la significación abierta de la imagen y encauzar al lector en el camino de la interpretación correcta.

De la necesidad ideológica se pasó al pragmatismo creativo y una nueva misión fue encomendada a la semiótica: según Eco (1968 [1989]), esta metodología serviría para la creación de un prontuario de recursos retóricos habituales, propios, que vendrían a ser como los universales funcionales de la publicidad. De esta manera, se ponía de relieve que la publicidad no posee un signo estéti$\mathrm{co}^{5}$ inherente, y que los usos llamados «creativos» debían traducirse más bien a «reiterativos» ${ }^{6}$.

No será hasta los ochenta cuando se retome esta cuestión semiótica en la publicidad. De mano del genial Floch (1993 [1991], 1995) se vuelve, de nuevo, a usar la semiótica, y esta vez con modelos empíricamente operativos, para dar cuenta no sólo de cómo se comprende una identidad de marca o un anuncio sino también para ayudar a creativos a generar mensajes comerciales, cambiar el posicionamiento de una marca o definir el tipo de publicidad que el creativo esta

${ }^{3}$ El propio Barthes junto a Greimas, Lévi-Strauss y Benveniste fueron promotores de la Escuela de París, bajo el impulso de Jakobson (Floch, 1993 [1991]: 24; Hénault, 1997 [1992]: 100) y en cuyo seno aún se siguen desarrollando preocupaciones semioticas sobre la publicidad (Nöth, 1995: 477).

${ }^{4}$ Péninou, influido por Barthes, mantiene que existen dos formas de hacer publicidad: la publicidad de "présentation « y la de "prédication « (Péninou 1972: 1949-1983)

${ }^{5}$ Lo característico de los códigos estéticos y sus mensajes, según Eco, estriba en su apertura. Gracias a esa apertura, de forma casi vacía, el espectador puede afrontar el reto de investir con sus propios contenidos dicha forma (1989 [1968]). En este mismo sentido se comprende la «función de autonomía» presente en el signo estético de Mukarovsky (1942), y la autorreferencialidad de Jakobson (1975).

${ }^{6}$ Para Anne-Marie Christin la reiteración publicitaria es la que permite salir de la paradoja inherente a la recepción publicitaria. Pues los anuncios son mensajes que se conciben para no ser vistos, por lo que nacen a sabiendas de que su lectura será distraída: «La forma en la que los vemos - es decir, sin mirar - determina el tipo particular de atención que solicita un cartel. Una atención esencialmente distraída, y por consecuencia, alejada de las preocupaciones que mobilizan al transehunte hacia otra cosa distinta de ese espectáculo absurdamente propuesto or el cartel. Es quizás por esta razón, consecuencia de esta situación paradojica - la imagen fija se opone como tal a aquel al que va destinada, puesto que es llevado por ella por un movimiento que ignora - que el cartel aporta la contradicción, porta la contradicción. Así, y esto confirma una vez más su diferencia respecto a la pintura, es esencial que el anuncio se repita» (Christin, 2001: 155). 
llevando a cabo en una campaña. Aplicando los conocimientos de sus precursores, $y$ aprovechando esencialmente toda la herencia greimasiana estructuralista, Floch consigue hacernos reflexionar sobre el discurso publicitario de manera sistemática. Nos muestra cómo bajo la superficie rica en signos de un anuncio se encuentra un itinerario concreto de sentido. Porque Floch, a diferencia de sus antecesores, no concibe la publicidad como un discurso maldito, sino, más bien, todo lo contrario: cada anuncio es un paraíso para el semiótico. Su actitud, libre de crítica ideológica, vino a demostrar que la semiótica podía ser, incluso, generativa, activa, ya que el significado no es algo dado, muerto, de ahí que el sentido publicitario no sea, ni mucho menos, pobre.

\section{APROXIMACIONES TEÓRICAS A NUESTRO MODELO DE ANÁLISIS}

El modelo de análisis que planteamos en este trabajo no nace, pues, ex nihilo sino que se asienta en la teoría semiótica europea postestructuralista que tiene como objeto de estudio el discurso, concretamente, las categorías básicas que componen un discurso, en sentido no sólo lingüístico, según lo concibe Fontanille (1998). Para este semiótico y lingüista, la unidad de atención para el estudio de la significación no puede ser otra que el discurso:

El discurso es la unidad de análisis de la semiótica (...) La instancia del discurso no es la de un autómata que ejerce una capacidad de lenguaje sino una presencia humana, un cuerpo sensible que se expresa' (Fontanille, 1998: 77)

El discurso se forja como una estructura donde la significación, no procede, sin más, de la suma o la combinación aleatoria de elementos significantes pues, además de los elementos significativos per se, es necesario tener en cuenta:

1. La forma sintáctica donde los elementos significativos toman suposición.

2. La orientación predicativa del acto de la enunciación ${ }^{8}$.

El discurso es una instancia de análisis donde la producción, es decir, la enunciación no puede estar disociada de su producto, lo enunciado (Fontanille, 1998: 81).

\footnotetext{
${ }^{7}$ Todas las referencias bibliográficas francesas citadas, en el texto y en las notas al pie, han sido traducidas del original por la autora.

${ }^{8}$ Estamos ante la trilogía inherente a todo lenguaje que como propone López García (1989) se compone de una pragmática físico-formal, que nos permite percibir los elementos significativos; una pragmática cognitivo-referencial, que nos dice sobre qué estamos hablando; y una pragmática comunicativo-funcional, que nos permite estructurar y relacionar todo lo anterior para comunicarlo.
} 
Ahora bien, la significación de lo enunciado, producto de una competencia comunicativa, es un objeto de estudio dinámico, que se transforma, que es versátil. La imposibilidad de aprehender científicamente el dinamismo en su variación nos obliga a centrarnos en la base del dinamismo que es la diferencia:

Cuando queremos analizar la significación de un discurso, no podemos sino basarnos en las diferencias, en las oposiciones entre los términos, las expresiones o las figuras (...). Entonces no encontramos otra cosa que contrastes, esto es, oposiciones en las que los términos están situados en lugares distintos dentro de la cadena discursiva. Lo cual viene a indicar que una diferencia, cuando se toma dentro de un texto, se presenta de hecho como una transformación entre dos contenidos, situados en partes distintas del discurso; de un lugar a otro, una categoría ha sido modificada, modulada deformada o invertida (Fontanille, 1998: 83).

Tal observación, de hecho, nos conduce al principio siguiente: en un discurso, el sentido sólo se aprehende en las transformaciones. Es el punto de vista del discurso lo que, además, neutraliza la diferencia entre texto y contexto evitando introducir a cada paso explicaciones que parecen foráneas al propio texto. El discurso es inseparable de unas circunstancias, de un cuerpo sensible que se expresa a través del mismo.

Por contra, desde el punto de vista del discurso se plantean otros problemas, básicamente a causa de la conjugación en un mismo proceso significante de varios modos semióticos: verbales, visuales, auditivos, proxémicos.

Debemos preguntarnos, en suma, cómo se constituye la red de interacciones inter-semióticas (Fontanille, 1998: 89).

El cariz fundamentalmente de forjado desde un punto de vista global permite una red de trabajo unificadora, no s6lo sobre las diferentes azoteas de la interpretación y organización del sentido, sino también de los diferentes acercamientos teóricos que constituyen, actualmente, el proyecto semiótico y que se encuentran reinterpretados e integrados en esta perspectiva.

Ahora bien, debemos precisar que Fontanille distingue dos sentidos en un mismo camino discursivo: el punto de vista del texto, que permite hacer un camino de la expresión hacia el contenido (un camino descendente), y el punto de vista del discurso propiamente dicho (el que produce un camino ascendente) que va desde las estructuras abstractas hasta las organizaciones concretas. En el primer camino, la perspectiva del texto puede ser calificada de hermenéutica (Ricoeur, 1986: 183-211) puesto que intenta buscar una explicación e intencionalidad subyacente en los hechos textuales, alcanzando al autor y al lector, mientras que en el segundo camino, realizado desde el discurso, cada etapa del recorrido está orientada a la producción, encauzando, controlando y convocando las distintas estructuras textuales para inscribirlas en una expresión. Es pues un camino generativo. 
Descubierta una semiótica que es capaz de dar cuenta de las emociones ${ }^{9}$ y pasiones de un individuo, la percepción y su papel en la significación, las relaciones con el mundo sensible y su connivencia con la fenomenología (Fontanille, 1998: 12) no debe extrañarnos que la orientación de la practica propuesta por Fontanille sea de tipo generativo más que analítico.

Como indica el autor, esta perspectiva semiótica es generativa, desarrolla «el punto de vista del discurso » mas que el «punto de vista del texto ». El manual presenta a partir del dispositivo présence-visée-saisie las condiciones de emergencia de la significación más que los procedimientos metodológicos de análisis de un dominio particular (Panier, 2000: 86).

En consecuencia, nuestra propuesta de análisis se convierte en un experimento de la validez de esta teoría, gestada en el nivel productivo, pero que puede servir, asimismo, como herramienta semiótica analítica:

Aplicando este modelo [el modelo semiótico] de análisis a las manifestaciones discursivas de una marca dada, es posible introducir un principio de organización en una materia que a primera vista se presenta como abundante y anárquica (Semprini, 1999: 150).

En el quinto capítulo de Sémiotique du Discours, titulado «Acción, pasión y cognición», Fontanille señala precisamente las tres grandes racionalidades discursivas que sirven para organizar la experiencia que sobre el mundo adquirimos mediante el discurso. Ya que el discurso está trabado como la armazón de tres lógicas inherentes (acción, pasión, cognición) en un grado, asimismo, ternario (nivel discursivo, nivel narrativo, nivel de valores) de producción/recepción discursiva. El itinerario generativo de sentido postula que, en su marcha hacia las formas completas de significación, se recorren tres etapas fundamentales. Si ejemplificamos con el discurso publicitario, los anuncios se constituirían en tres niveles:

a) Nivel de valores. Es el más profundo, donde se instalan los valores que fundan el discurso y la identidad de la marca. Se trata de un número necesariamente limitado y determinan, de algún modo, el código genético de la marca.

b) Nivel narrativo. A medida que la significación toma forma, se organiza en estructuras narrativas, sistemas de oposiciones, esquemas de actores que actualizan estos valores en dicho nivel.

\footnotetext{
${ }^{9}$ Véase Greimas-Fontanille (1994 [1991]), Parret (1982a, 1982b), Zilberberg (1981).
} 
c) Nivel discursivo. La significación alcanza el último grado del itinerario cuando llega al nivel discursivo, donde los valores son revestidos para la comunicación eficaz: se visten con los signos y los códigos del universo sociocultural que nos rodea.

Nuestro recorrido deber realizarse necesariamente a la inversa (del nivel discursivo al nivel de valores), analizando las grandes racionalidades ${ }^{10}$ que nos sirven para organizar nuestra experiencia: la acción, la pasión y la cognición. Dentro de estas tres grandes racionalidades, nos interesa evaluar el comportamiento de categorías que se dan tanto en la palabra como en la imagen. Categorías de análisis lo suficientemente amplias como para dar cuenta de procesos significativos creados de manera conjunta entre distintos códigos. Esto es, optamos por no tratar las peculiaridades formales per se que proceden de la percepción y procesamiento de los sistemas significantes y que dependen del canal de comunicación escogido, pues lo que nos interesa es servirnos de ellas para llegar a un nivel más profundo de significación. Tal opción resulta de especial relevancia en discursos como el publicitario, donde los elementos mínimos se componen apoyándose en unidades más amplias procedentes de otros códigos de partida, por lo que el intento de descripción y análisis sería interminable si procediéramos, no obstante, a tenerlas en cuenta. Del mismo modo que resulta innecesario la distinción entre niveles de connotación y denotación, ya que toda publicidad es intencionalmente retórica por principio y lo fue en su principio. Nuestra labor debe ceñirse a la observación de las estrategias semióticas publicitarias y cómo éstas han variado en un espectro temporal y un medio (el gráfico, en nuestro caso) concretos.

\subsection{La acción}

La lógica de la acción reposa sobre la transformación discontinua de los estados de las cosas. Una acción engarza dos situaciones una final y otra inicial cuyos contenidos específicos se invierten [ $(\mathrm{S}$ U O $\rightarrow \mathrm{S} \cap \mathrm{O}$ ) o bien ( $\mathrm{S} \cap \mathrm{O} \rightarrow$ $S$ U O)]. La unidad de base del enunciado de acción es el programa narrativo (PN) (Greimas-Courtés, 1982 [1979]: ad vocem). Dicha unidad de base se produce como consecuencia de la interacción de dos tipos de actantes lógicos, el sujeto $(\mathrm{S})$ y el objeto $(\mathrm{O})$, reunidos por un predicado de junción, que puede ser de conjunción ( $\mathrm{S} U \mathrm{O}$ ) o disyunción ( $\mathrm{S} \cap \mathrm{O}$ ). Una transformación ocurre cuando se pasa de un estado a otro. Y para que se desarrolle este PN debe existir un desencadenante, que será considerado como un agente de transformación.

\footnotetext{
${ }^{10}$ «Organizar una experiencia para hacerla discurso, es ante todo, descubrir (y/o proyectar) una racionalidad - una dirección, un orden, una forma intencional, esto es, una estructura - » (Fontanille, 1998: 183).
} 
Encontramos aquí la presentación tradicional de los esquemas narrativos canónicos ${ }^{11}$ y los antiprogramas.

En los esquemas de Propp (1977 [1928]), se distinguen los referidos a la prueba y los referidos a la búsqueda. En los esquemas llamados de prueba se produce una confrontación que lleva a una dominación que genera una apropiación o desposesión. La apropiación es el esquema que beneficia al vencedor, y la desposesión la que afecta al otro sujeto, considerado como perdedor.

Sólo la última parte de este esquema de prueba puede traducirse en una lógica de transformación. Como señala Fontanille (1998: 110) el estado de confrontación es sólo une mise en présence de dos actantes y sus programas; sin este reconocimiento de presencias en un mismo campo discursivo, jamás se llevaría a cabo la prueba. En muchas ocasiones en la narración sólo aparece esta toma de posición, que es un posicionamiento respecto a un mismo punto de referencia.

En cuanto a la dominación, que supone la siguiente etapa, antes de ganar o perder el objeto, los sujetos deben comparar sus fuerzas, «medir» a su adversario, lo que equivale a tomar una posición dominante. Fontanille indica que esta dominación puede expresarse en términos de modalidades de presencia pues «el vencedor es aquel cuya presencia es más fuerte; se sitúa en el centro del campo de referencia» (Fontanille, 1998: 111) y también en modalidades de la competencia dado que «el poder hacer de uno afecta al poder hacer del otro» (íb.). Pero incluso en términos modales la dominación es una cuestión de intensidad y de cantidad.

El esquema de la búsqueda pone en relación cuatro tipos de actantes: el destinador y destinatario, el sujeto y el objeto. El destinador y destinatario aparecen porque el esquema narrativo produce, fundamentalmente, una transferencia de objetos de valor. Se trata de una definición de valores que dan sentido al recorrido del sujeto.

\subsection{Pasión}

La racionalidad propia de la pasión es la de la irrupción de los afectos en el discurso, la que muestra las tensiones afectivas. La pasión obedece pues, a una lógica tensiva y se analiza a partir de la modulación de la intensidad y de las formas de cantidad (Panier, 2000: 82). Esto es, para investigar el lado pasional de un discurso debemos de tener en cuenta los signos pasionales establecidos en lexemas e iconemas pasionales, el ritmo, la perspectiva, la modalidad empleada, los códigos somáticos y los figurativos que producen los efectos pasionales del discurso:

${ }^{11}$ El programa narrativo (PN) es la unidad mínima de la narratología, que postula la universalidad de la categoría relato en todas las estructuras discursivas: «El relato está presente en todos los tiempos, en todos los lugares en todas las sociedades; el relato comienza con la historia misma de la humanidad; el relato está allí como la vida» (Barthes, 1986 [1982]:9). Tal metodología nace de fuentes claramente antropologicas (Propp, 1977 [1928]; Dumézil, 1968; Lévi-Strauss, 1985 [1958]) que obtuvieron un refinamiento teórico en la escuela estructural francesa de la mano de Greimas (Parret, 1997: 2303), Genette y Todorov. 
Estas formas son (afortunadamente) estabilizadas en códigos identificables, cuyo conjunto constituye lo que hemos llamado la racionalidad de la pasión y que, justamente, permiten reconocerla cuando ésta aparece (Fontanille, 1998: 213).

Tales esquemas se establecen mediante códigos: por parte de lo sensible, códigos somáticos y figurativos, por parte de lo inteligible, códigos modales, perspectivos y rítmicos

Volvamos a los inicios: la toma de posición. Ésta presupone un cuerpo propio que instala un campo de presencia con una profundidad que puede ser evaluada: a estos dos elementos, el cuerpo que toma una posición y la profundidad del campo de presencia, corresponden respectivamente los códigos somáticos y los códigos perspectivísticos de la pasión (íb. 214).

A propósito de este campo de presencia, debemos anotar que la intensificación y multiplicación de la imagen ha desempeñado un rol esencial en la publicidad, como veremos más adelante. Landowski señala acertadamente que:

Independientemente de las concepciones o prejuicios que su modo de construcción refleja, independientemente también de lo que representa, una imagen es ante todo en ella misma una presencia. Nos pone inmediatamente en contacto con algo que no es un discurso sobre alguna cosa ni un discurso sobre un supuesto referente (...) sino que es, ni más ni menos, la presencia de la imagen como realidad plástica (Landowski, 1997: 154).

En este preciso sentido se orientan las estrategias creativas en publicidad. La idea de que un anuncio nos sacude el pensamiento o que, como el arte, intensifica las emociones, ratifica lo afirmado por Fontanille: hay un cuerpo sensible que se instala en un campo de presencia y siente.

La razón se comporta con tal lentitud y con tantas perspectivas sobre tantos principios, los cuales deben estar siempre presentes, que en todo momento se adormece o se desorienta pese a tener todos estos principios presentes. Los sentimientos no actúan así: se originan en un instante y siempre están preparados para actuar (Pascal, pensée $\mathrm{n}^{\circ}$ 671).

\subsection{La cognición}

La cognición es el resultado de la manipulación del «saber» en el discurso. Se consideran de este modo todos los códigos que conforman un discurso desde el punto de vista de los conocimientos que son susceptibles de darnos. El discurso así entendido se percibe como una estructura, un todo inteligible (Panier, 2000: 82). La cognición obedece a la lógica epistémica que revela las formas de aprehender la experiencia del mundo. 
En realidad, las tres grandes lógicas (lógica de la acción, lógica de la pasión y lógica de la cognición) son formas distintas de percibir y construir una significación del mundo que no cesa. La lógica de la acción se encarga del sentido manifestado a través de una programación transformativa del mundo. Esta lógica respondería a la pregunta ¿qué ocurre en el mundo? La lógica de la pasión se ciñe al sentido de lo experimentado corporalmente (todos los hechos que afectan al campo de la presencia), respondiendo a la pregunta ¿cómo se siente lo que ocurre en el mundo? La lógica de la cognición se acerca al sentido de lo comunicado, elaborando, o no, nuevos saberes sobre el principio del descubrimiento. Tal lógica respondería a la pregunta ¿qué descubro del mundo? A cada una de estas racionalidades le corresponde su propia forma de concebir el cambio

Cuando Greimas reconoce, a propósito de las dificultades considerables que le plantea la interpretación figurativa de un cuento de Maupassant, la necesidad de tener en cuenta un procedimiento complementario de lectura, que consiste en confrontar el mensaje recibido con el universo referencial del saber del destinatario (Greimas, 1989: 124), en realidad, está tratando de la problemática de la cognición, de la integración de lo desconocido en lo conocido. Tal actividad no puede ser considerada como meramente «enciclopédica» (Greimas, 1989: 133), sino como una red de relaciones semióticas formales, entre las que el sujeto epistémico selecciona las equivalencias que necesita para asumir la validez del discurso.

Greimas muestra que estos lugares formales son susceptibles de articulaciones distintas, en las que podemos reconocer una estructura elástica, tensiva, que oscila entre el saber y el creer.

\begin{tabular}{|l|c|c|}
\cline { 2 - 3 } \multicolumn{1}{c|}{} & CREER & SABER \\
\hline Contenidos cognitivos & $\begin{array}{c}\text { Creencias } \\
\text { («falso conocimiento») }\end{array}$ & $\begin{array}{c}\text { Ciencias } \\
\text { («verdadero conocimiento») }\end{array}$ \\
\hline Estrategia cognitiva & Persuasión & Convicción \\
\hline Origen conocimiento & $\begin{array}{c}\mathrm{S}_{1} \text { (exterioridad) } \\
\text { manipulación }\end{array}$ & $\begin{array}{c}\mathrm{S}_{2} \text { (interioridad) } \\
\text { reminiscencia }\end{array}$ \\
\hline Relación con el objeto & $\begin{array}{c}\text { inmediata, no } \\
\text { aspectualizada }\end{array}$ & $\begin{array}{c}\text { mediada, aspectualizada, } \\
\text { con resistencia del objeto }\end{array}$ \\
\hline $\begin{array}{l}\text { Relación dominante en } \\
\text { el sintagama intersubjetivo }\end{array}$ & $\begin{array}{c}\mathrm{S}_{2}-\mathrm{S}_{1} \\
\text { (unión con personas) }\end{array}$ & $\begin{array}{c}\mathrm{S}_{2}-\mathrm{O} \\
\text { (unión con ideas) }\end{array}$ \\
\hline Figuras dominantes & $\begin{array}{c}\text { consenso, acuerdo, } \\
\text { identidad }\end{array}$ & $\begin{array}{c}\text { desacuerdo, discusión, } \\
\text { alteridad }\end{array}$ \\
\hline
\end{tabular}


Así se constata que existen una serie de ejes semánticos sobre los que se oponen los universos axiológicos de creer y saber (Fontanille, 1982: 11). La diferencia entre estos dos modos de aprendeher el mundo radica en la valorización del objeto cognitivo. Si el objeto cognitivo se relaciona con otros objetos cognitivos con la única finalidad de apreciar lo aportado, esto es, la diferencia en su valor de conocimiento, se trata de un simple saber. Si se valoriza, teniendo en cuenta, a la vez, otros objetos con sujetos (entre los que se encuentra el propio observador), la confrontación incluye no sólo objetos cognitivos sino universos de asunción, esto es, de creencias.

Evidentemente, la realidad discursiva es mucho más compleja, de manera que, con frecuencia, no resulta fácil distinguir entre estos dos niveles de pertinencia cognitiva (Greimas, 1983: 116; Fontanille, 1998: 223, Geninasca, 1997: 59), por lo que se puede hablar de una dominancia de uno u otro nivel.

Si establecemos una relación lógica entre estos dos términos, encontraremos una relación tal que:

\section{valores referenciales informativos}

valores técnicos científicos

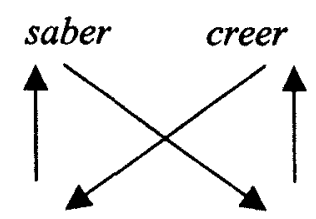

no creer no saber valores simbólicos míticos

valores sensibles hedónicos

\section{racionalidad racionalidad informativa mítica

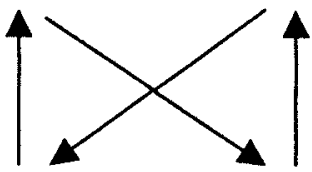 \\ racionalidad técnica \\ racionalidad hedónica}

Si aplicamos estas cuatro categorías, cuatro maneras distintas de valorizar el descubrimiento de un objeto cognitivo, a la publicidad, estaremos considerando, por tanto, cómo se presenta este objeto cognitivo para el futuro consumidor. Aunque, en la medida en que la publicidad nos plantea un discurso sobre un objeto frecuentemente conocido de la realidad, la racionalidad cognitiva, salvo 
en lanzamientos de nuevos productos, más que centrada en el conocimiento per $s e$ del objeto está centrada en valores que tienen que ver, o bien con el uso racional del mismo, valores informativos, o bien con valores de base, concebidos, asumidos, mediante creencia como tales, esto es, valores míticos. A estos valores míticos se les oponen aquellos valores asentados en la no creencia, es decir es, en la comprobación empírica o técnica del uso, de ahí que se denominen de tipo crítico. La valorización racional, informativa se contradice con aquellos valores que niegan a los valores de uso, como lo son todo los valores que potencia lo hedónico o lúdico. Tal y como señala Floch (1993: 161), existe toda una axiología del consumo que se puede centrar en uno o varios de estos valores:

a) La valorización práctica que corresponde a los valores de uso, concebidos como contrarios de los valores de base (se puede hablar de valores de utilidad) y reside en la información del producto, en lo referencial.

b) La valorización utópica que corresponde a los valores de base, concebidos, una vez más, como contrarios de los valores de uso, y que se refieren a la construcción mítica del objeto publicitado.

c) La valorización lúdica que supone la negación de los valores utilitarios los cuales están relacionados con el lujo, el hedonismo y la sensualidad.

d) Y por último, la valorización crítica que supone la negación de los valores de base o existenciales y que se vincula con la información técnica que aprecia los objetos cognitivos propuestos sobre explicaciones locales, aisladas y desmitificantes.

Estas valorizaciones no tienen por qué ser estáticas. En un mismo anuncio se pueden recorrer todas las posibilidades, tal y como ha señalado Floch (1993: 161), aunque lo habitual es que en las producciones textuales uno de esto valores sea el dominante. Veamos como podemos utilizar esta metodología en una aplicación concreta a la publicidad española de alcohol de los años cincuenta.

\section{LOS ANUNCIOS DE ALCOHOL ESPAÑOLES EN LA DÉCADA DE LOS CINCUENTA}

\subsection{La narración como atribución básica}

Los programas narrativos de los anuncios de bebidas alcohólicas en estas fechas son muy básicos: se trata del saber-hacer del producto puesto que todo gira en torno a la alabanza y utilidad del mismo. El producto, representado ico- 
nica y verbalmente, adopta una función autorreferencial, pues está ahí para representarse a sí mismo, trasladándose del plano simbólico al comercial, otorgando un referente al nombre que lo designa. Son programas, pues, que sirven para el reconocimiento del producto en cuanto referencia extratextual. Este programa narrativo se concibe fundamentalmente desde la atribución por incompetencia de la marca para apropiarse de unos valores en juego: de ahí que necesite un $\mathrm{S}_{3}$ o sujeto ayudante que le atribuya las cualidades por las cuales se distingue de sus competidores. El $\mathrm{S}_{3}$ coincide, en determinadas ocasiones, con el rol del sujeto consumidor, esto es, con una presencia antonomásica del mismo: los actantes humanos que aparecen en escena se constituyen en los consumidores potenciales del mismo, creando una identificación narrativa del personaje con el lector, prometiendo ciertos valores del objeto publicitado.

En el caso de los anuncios de bebidas alcohólicas de la década de los cincuenta, los grandes valores que se atribuyen a las marcas publicitadas se centran en la exclusividad, asociada a lo exquisito; en la españolidad, vinculada al carácter nacional del consumo; y en la tradición como valor incuestionable. Todos estos valores dan una imagen de la antigua hidalguía española quijotesca, del quiero-y-no-puedo, del orgullo nacional, de la veneración de las tradiciones propias como forma de prestigio. Bien es cierto que todas estas valorizaciones se concentran fundamentalmente en los anuncios del brandy/coñac, puesto que tales productos se basan, esencialmente, en el concepto de lo 'añejo', pero aparecen, del mismo modo, en otros tipos de destilaciones como licores, champán o anís, todos de absoluta producción nacional (Soberano -de González Byass-Fundador, Carlos III -de Pedro Domecq-, 1900, Terry -de Fernando A. de Terry-, Calisay -de Destilerias Molfulleda-, Veterano, Independencia, Magno -de Osborne-, Anís la Cordobesa -de Cruz Conde-, Anís La Praviana -de Juan Serrano e hijos - etc.). No existen en la práctica anuncios de bebidas de trago largo, tales como el vodka o el whisky, por lo que su paulatina introducción en el panorama publicitario español simbolizará un cambio de mentalidad social y consumista y, por ende, publicitaria.

\section{a) La españolidad como argumento}

De ese modo no sólo se denomina al coñac 'jeriñac' y a la ensaladilla rusa 'ensaladilla nacional' sino que también se cambio el nombre de ciertas marcas para resaltar las gestas de las pasadas guerras como el Anís 'Piedras de Toledo' (Vázquez Montalbán cit. en Alonso-Conde, 1994: 123).

Entre los valores atribuidos a las bebidas alcohólicas para persuadir a su consumo están los valores nacionalistas españoles, por lo que podemos asegurar que la propaganda política 'infectó' también a la publicidad comercial hasta bien entrada la década de los sesenta. Las propias denominaciones de los alcoholes son muy elocuentes, esencialmente, las marcas de brandy: Carabela, Lepanto, Independencia, Magno, Veterano, Galeón, Fundador, Felipe II, Carlos I, Carlos III o Soberano. 
Todas ellas reflejan valores circunscritos al régimen dictatorial de la época. que utiliza hechos históricos que ensalzan los valores de la raza: el pasado glorioso, la victoria, el descubrimiento de las Américas o la prepotencia cultural.
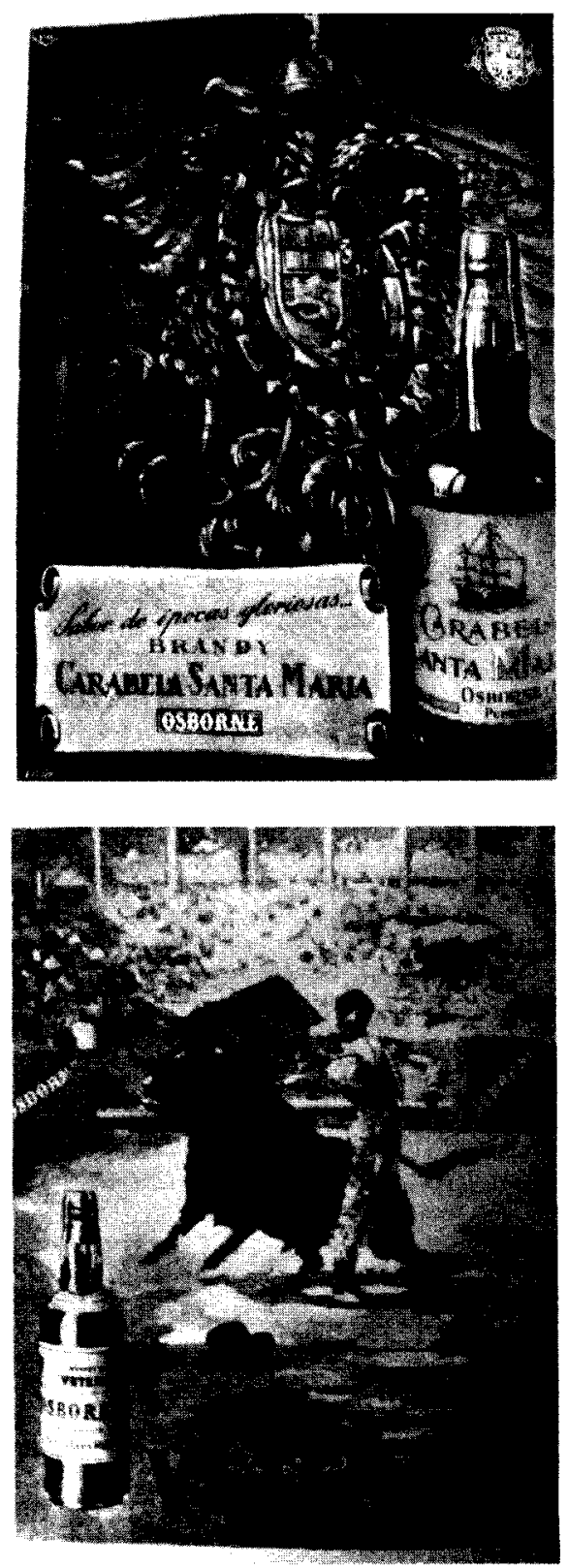
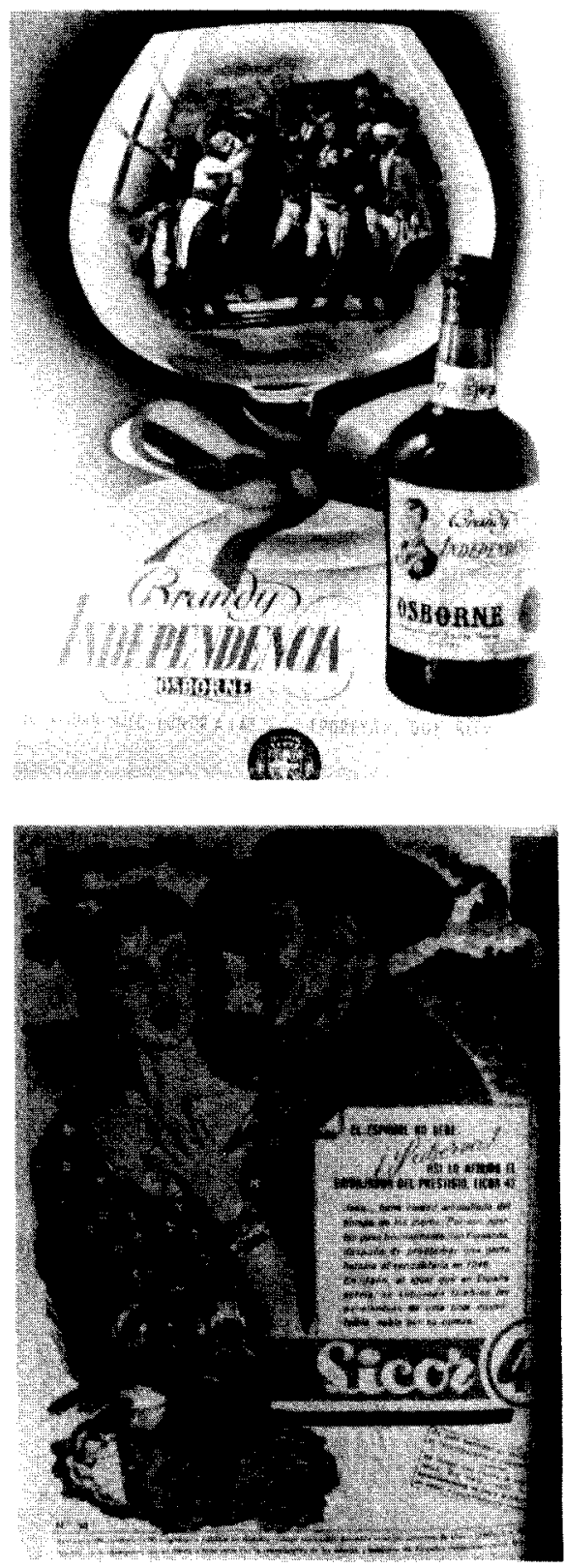
A estos valores bélicos o de conquista se les añaden los valores folclóricos, representados por las costumbres populares españolas, las corridas de toros, la castiza belleza femenina, que conforman las señas de hipanidad ${ }^{12}$. La simpatía hacia estos valores, inherentes al régimen, suponían, desde el punto de vista económico, promover la producción y consumición dentro de los límites nacionales - tal y como mandaba la autarquía - y, desde el punto de vista simbólico, la atribución al producto de valores ya «ensalzados», de sobra reconocidos en la sociedad de la época, y, sobre todo, valores de diferenciación que se constituían y encarnaban en el propio sujeto-consumidor.

Aunque a día de hoy tales anuncios pueden parecernos, desde el punto de vista del contenido, más o menos reprobables o demodé, lo cierto es que en sus estrategias latía, aunque de forma involuntaria, una óptica nueva de creación textual, en la medida en que los objetos de valor propuestos se relacionaban más con la esfera de significados del consumidor que con la del propio producto.

En el caso de la españolidad como valor de atribución se apunta al sujetomarca y al sujeto-consumidor sirviéndose fuertemente de la presencia de éste en escena para convertir al anuncio en una alabanza doble. Al incluir en el espacio significativo valores que distinguen doblemente, al objeto y al sujeto, se apuesta por una estrategia de valorización segura, puesto que enuncia y relaciona dos identidades, que, en principio no tiene una relación mas allá del anuncio. A pesar de que estos valores entrañen hoy día una visión arcaizante de la publicidad, debemos considerar el acierto de mostrar valores que se incrustan en la esfera significante del sujeto-consumidor. La españolidad, como identidad del sujeto, se estructura en dos grandes apartados: el pasado glorioso y los elementos folclóricos.

\section{a.1 El pasado glorioso}

Sin memoria no es posible definir una identidad personal o colectiva. La identidad fundamental del individuo o del grupo que le confiere su personalidad y carácter específico toman su base sobre esa parte de la memoria que se encarga de desgajar aquellos trazos que van a perdurar y a mantenerse por un periodo de duración ${ }^{13}$. De esta manera, la identidad tiende a confundirse con lo permanente, lo tradicional, con aquello que es heredado ${ }^{14}$. En el caso de los

\footnotetext{
12 «A partir de los años 50 comienza a producirse toda una organización del turismo en torno a esta amalgama de valores nacionales y de la 'diferencia'. Es el typical Spanish que, algunos años más tarde, las autoridades oficiales, bajo la dirección de Manuel Fraga Iribarne, van a promover y vender para un mayor bienestar de los españoles» (Ancelot, 1997: 15).

${ }^{13}$ Véase los distintos estudios sobre la identidad (desde el punto de vista psicológico, sociológico y político) en Ruano-Borbolan (1998).

${ }^{14}$ «Más allá, la ideología y la mentalidad tradicional han hecho de la identidad un producto necesario de una naturaleza intencionalmente inamovible, alimentando así la idea de que esta misma identidad se conservará en el futuro sin alterarse jamás » (Ruiz Torres, 2001: 133)
} 
anuncios que nos ocupan es más que evidente el uso político que se hace de la historia de España y del concepto de identidad nacional:

Todo esto fundaba la unidad indefectible de España y daba sentido a la lucha contra todo tipo de invasiones, herejías, tendencias separatistas e ideologías laicas perniciosas y anti-españolas por naturaleza (...). Cuando España se había beneficiado de buenos gobernantes, que no buscaban imitar otras naciones sino a «mantener las virtudes de la raza» supo lograr el máximo imaginable de su grandeza imperial (Ruiz Torres, 2001: 142).

Dentro de esta grandeur impériale se insertan los anuncios de brandy Carabela (fig. 1) y brandy Independencia (fig. 2). El primero se despliega como un espacio sobresaturado de símbolos histórico-políticos:

- El escudo que aparece en la imagen es el de Toledo ${ }^{15}$ que concentra los valores de la raza hispánica, muchos de los cuales aparecen en el actual escudo de España ${ }^{16}$ : los símbolos de Castilla y León, la reconquista de Granada, el águila bicéfala de los Reyes Católicos, las columnas hercúleas, el toisón de Oro de Carlos V y la corona imperial, esculpido en un colosal monumento de piedra. No en vano este escudo tiene un haz de rasgos que pueden considerarse como el emblema semiótico del «imperio español nacido en Castilla» ${ }^{17}$.

- La estética de la botella de brandy, en la que distinguimos, asimismo, la imagen de la Carabela Santa María botada en el mismo puerto en el que se fabrica el susodicho brandy: Santa María de Cádiz.

- El eslogan «Sabor de épocas gloriosas...» en tipografía manuscrita desplegado en un papiro que posee las mismas características físicas que la etiqueta a partir de la cual se crea una correlación visual por identificación.

\footnotetext{
${ }^{15}$ Véase el libro elaborado por el Ministerio para las Administraciones Públicas (M.A.P), Banderas y escudos de las provincias de España, 1991.

1" Para el estudio de la variación histórica del escudo español, véase AA.VV. (2000): Símbolos de España.

${ }^{17}$ El águila bicéfala representaba en el siglo XV a los Reyes Católicos. Carlos V añadió al escudo el toisón, las columnas hercúleas y la corona imperial (además de las armas de Flandes. Borgoña, Brabante y Tirol). En la época de Felipe II, Felipe III, Felipe IV y Carlos II, la corona imperial ya desaparece, como símbolo de la pérdida de colonias, terrenos y poder. Durante el franquismo se suele utilizar el tipo de heráldica que fue común durante el reinado de los Reyes Católicos, puesto que en éstos no se hace referencia, lógicamente, a las posteriores dinastías de Austria, y, además, Castilla y León pasan a ser sinónimo del germen de España y del origen de la raza. El escudo de Toledo se presenta, por tanto, como una atractiva y peculiar combinación de rasgos heráldicos que los hacen especialmente representativos del glorioso pasado imperial de los españoles. Véase el aparatado «Símbolos del Estado» en www.la-moncloa.es.
} 
Todo estos símbolos, cual emblema, reenvían a la misma referencia: al pasado glorioso en el que España era un Imperio: «Sabor de épocas gloriosas...». De este modo, se elige una etapa histórica, filtrada a través de los símbolos del escudo, que abarca desde de los Reyes Católicos hasta Carlos V, un periodo muy significativo para la mentalidad del colectivo español de la época ${ }^{18}$ ya que se considera, tras la Reconquista, como el momento de apogeo de la hispanidad: unificación religiosa y política, la creación del Tribunal de la Santa Inquisición y el descubrimiento de América (Ruiz Torres, 2001: 141). Estos tres acontecimientos vienen representados mediante símbolos inequívocos: el Escudo coronado con la corona imperial, rematado con el toisón de oro, y la presencia de la Carabela.

La España de los Reyes Católicos desempeñará, sin lugar a dudas, un papel de primera magnitud en los ideales del régimen y el NO-DO así lo confirma. El significante más reiterado respecto a los Reyes Católicos es, junto a la idea de Imperio, el de la unidad nacional, principio sacrosanto del Nuevo Estado:

El quinto centenario del nacimiento de quienes llevaron a España a la cima de la gloria es conmemorado así, con el máximo esplendor y en presencia de Franco, continuador insigne de la unidad española de nuestros días (NO-DO, 511A, 1952, en Tranche-Sánchez Biosca, 2001: 460).

El segundo anuncio (fig. 2) también se refiere a la gloriosa memoria de antaño, y, como en el caso anterior, la vinculación de un hecho histórico con un producto se debe, precisamente, a la denominación otorgada a éste. El brandy Independencia se inscribe en esta tendencia discursiva de la historia propagandística haciendo referencia a la Guerra de Independencia Española y a la victoria de los españoles respecto a la dominación francesa. El cuadro que encierra la copa es de Casado del Alisal ${ }^{19}$ en el que se representa la victoria lograda por el general español Francisco Javier Castaños sobre el francés Pierre-Antoine Dupont en la estratégica localidad de Bailén y que permitió a los ejércitos españoles abrirse camino hacia Madrid.

Los textos, las alocuciones y los discursos de Franco son unánimes en un punto: el desprecio, o incluso más el intenso odio hacia el siglo XIX; centuria que, de acuerdo con el discurso oficial, añadió al racionalismo libre pensador (y la consiguiente religiosidad contrarreformista), el liberalismo político y, para

\footnotetext{
${ }^{18}$ Fundamentalmente debido al uso propagandístico de la historia, tanto en el medio escolar, véase Martínez Tórtola (1996), como en el medio extraescolar, véase Cirici (1977).

${ }^{19}$ José Casado del Alisal (1832-1886) pintó en 1864 en París este cuadro titulado La rendición de Bailén. Según Álvarez Junco, este pintor pertenecía al grupo de artistas defendidos por su visión conservadora de la historia por el Partido Moderado: «Frente a esta plasmación progresista del pasado nacional, los conservadores contraatacaron: el partido moderado declaró su preferencia por Casado del Alisal... Poco después, con La rendición de Bailén, este pintor reflejaría las glorias nacionales contemporáneas con estilo velazqueño apenas disfrazado» (Álvarez Junco, 2001: 255).
} 
colmo de males, la consumación de la decadencia imperial española. Ni qué decir tiene que el siglo XVIII, siglo de las luces, pasó como una sombra o, quizá más aún, como un vacío en el noticiario. Apenas un gesto recoge el NO-DO de estos doscientos años pero lo hace con ahínco, entusiasmo y beligerancia incontinentes: la sublevación española contra la invasión napoleónica (Tranche-Sánchez Biosca, 2001: 465).

Lo que resulta a todas luces evidente es que en ambos textos el valor que se le atribuye al producto, «la hispanidad», producen una exaltación que engloba al consumidor y al producto en un mismo dominio significativo: la identidad nacional. Hallamos ya una incipiente pero novedosa táctica de crear junto al producto una imagen de empresa que lo respalde. Como comprobaremos a continuación, tal identidad nacional se registra bajos otros matices más populares y festivos pero con igual eficacia en esta década publicitaria que nos ocupa.

\section{a.2 Los valores folclóricos}

Si nos detenemos ahora en los dos anuncios siguientes, Osborne, Veterano (fig. 3) y Licor 43 (fig. 4) comprobaremos que existe otra forma menos bélica pero igualmente eficiente para destacar el valor de la hispanidad, y que lo constituyen, entre otros clichés de la imagen de España, la corrida de toros y el folclore andaluz.

El anuncio de Licor 43 presentado bajo el eslogan de «El español no bebe, saborea" ostenta un cuerpo textual que entronca, en cierta medida, con ese leitmotiv de conquista bélica que comentamos en el apartado anterior, ya que de Jaén se destaca: «Bella ciudad amurallada del tiempo de los moros. Por sus puertas pasó triunfalmente San Fernando, después de proclamar una gesta heroica al conquistarla en 1246. En Jaén, al igual que en España entera, se saborean también las excelencias de este licor insustituible, noble por su pureza...» junto a una imagen que sirve como refuerzo, ya no a la denotación de lo dicho (como hemos constatado en ejemplos previos) sino la connotación del eslogan. El enunciado «El español no bebe... ¡S Saborea!» tiene como función perlocutiva transmitir un contenido de jactancia o presunción que se refuerza en la ilustración mediante la acción del requiebro valentón. El motivo de esta imagen sirve, pues, para visualizar esa vanagloria ponderada de lo hispánico, a la vez que presenta un haz de estereotipos de la raza con gran suerte en la literatura histórica: la de la belleza española - fundamentalmente la belleza andaluza - y que se resuelve en el estereotipo de Carmen ${ }^{20}$, el mito del conquistador español o el mito de Don Juan, el motivo del piropo y el de la pasión española, así como el de la fiesta.

\footnotetext{
${ }^{20}$ Todos estos clichés o imágenes estereotipadas se recogen y se explican bajo tales voces (piropo, Carmen, Don Juan) en Ancelot (1997). Nos ha resultado de gran utilidad la visión histórica del estereotipo español en Álvarez Junco (2001) y Núñez. (2001).
} 
Bastará simplemente con que en Carmen Mérimée traslade con pocas variaciones esas sensaciones de la España vivida y soñada. Las licencias poéticas harán el resto. De ese modo quedará plasmada sobre el papel la quintaesencia de una determinada España, ni verdad, ni mentira, sino todo lo contrario: Andalucía y sus tipos como marco privilegiado, la vida romántica de los bandoleros, las posadas tenebrosas, las corridas de toros como tragedia moderna, la sensualidad del baile flamenco, el rasgueo de guitarras, gitanos, contrabandistas y mujeres fatales (Núñez, 2001: 154).

En el caso de Osborne, esa vinculación resultó especialmente feliz ya que crearía la que a, nuestro juicio, es la primera imagen de marca o, si se prefiere, de empresa - muy anterior a Nike - en la historia de la publicidad española, puesto que logró relacionar un concepto abstracto, la hispanidad, con un signo visual concreto, el toro ${ }^{21}$, originando la imagen de marca o identidad Osborne. Comparado con otras estrategias de narración, en las que predominan fuertemente las transformaciones por atribución y las relaciones internas entre los elementos visualizados y los verbalizados son siempre de tipo subordinado de aquellos respecto a éstos, este anuncio sirve como excepción que confirma la regla del quehacer textual de la época.

En primer lugar, porque ya no es una atribución de valores sino una apropiación que el producto realiza por sí mismo. No hay un sujeto ayudante, ni existe la presencia del sujeto-consumidor que dote de contenido al sujeto-marca. En esta ocasión el sujeto-marca, aunque unido todavía al objeto comercial, tal y como lo demuestra la presencia de la botella ${ }^{22}$, se sitúa en el coso taurino, anunciándose en las barreras y concluyendo la imagen a modo de firma. En segundo lugar, la predicación de valores se realiza exclusivamente mediante la imagen sin la presencia de una predicación verbal.

Lo que llamamos «conclusión» o «rúbrica» corresponde a la posición espacial que todas las marcas utilizan en sus discursos, esto es, a la ubicación de los logotipos e imagotipos en la parte inferior derecha del texto. Tal emplazamiento se ha constituido en una práctica habitual publicitaria, no en sentido legal, sino semiótico, de un uso discursivo regular. Desde el punto de vista perceptivo, la mirada que sigue un itinerario de izquierda a derecha y de arriba abajo, barrido en Z, converge al final en este ángulo inferior derecho (Sutil Martín, 1991) de

${ }^{21}$ La idea de vincular toros y vino de jerez ya se le había ocurrido previamente a la empresa Domecq (1930) y no en vano de esta ganadería saldría una partida que, a través da algunos intermediarios fue a parar a manos de J. L. Osborne Vázquez (1952). La agencia Azor llevó durante esta década la publicidad de Osborne y entre sus colaboradores tenía contratado a Manuel Prieto, grabador de la Fábrica Nacional de Moneda y Timbre, que en al año 1956 optó por una idea que conjugara los toros y el brandy diseñando el famoso toro. En noviembre de 1957 comienzan a instalarse los primeros que llegaran a 500 aunque en la actualidad sólo quedan 90 , de los cuales 21 se encuentran en Andalucía.

${ }^{22}$ Algo muy habitual en la publicidad de alcohol (como lo es la presencia de la cajetilla en la publicidad de tabaco). 
manera que, en el barrido de lectura los últimos signos leídos son, fundamentalmente, los que pertenecen a la marca. Pero, además de este valor estratégico-perceptivo, existe otra función, que podemos denominar de pertenencia o autoría, en cuanto que todo lo comunicado en la parte textual «narrativa» desemboca en la marca como generadora, principio y fin, de tal sentido.

Esta operación de sintaxis visual requiere un orden de lectura del tipo $\mathrm{V}+$ $\mathrm{S}(\mathrm{O})$ en el que una predicación se realiza por un sujeto marca para sí mismo, esto es, se produce una apropiación de lo manifestado en el discurso mediante la metonimia: al final se presenta la marca como parte representativa de todo lo predicado en el texto.

En general, las dos grandes operaciones fundamentales de evolución de los programas narrativos publicitarios en la imagen se ciñen a la constitución de un sujeto-marca por metonimia reiterada y unos valores atribuidos mediante el procedimiento metafórico, ambos de presencia continuada en el acervo publicitario. En este sentido, las dos funciones del lenguaje más carismáticas para Jakobson lo son también para la imagen publicitaria.

Estamos ante una nueva forma de metonimia, la metonimia por contigüidad, que transmite el sentido por asociación, permitiendo la gestación de una historia al poner el producto en estado de narración (Jakobson, 1975: 121).

Como señala Sánchez Corral (1997: 133) no es que esto ocurra en una serie específica de anuncios, sino que es una tendencia general, nosotros añadimos, diacrónica, del discurso publicitario. La elaboración de la fábula como economía calculada de medios, a fin de poder expresar una profusión de actividades por parte del producto, se realiza esencialmente en virtud de una economía sintáctica en la que se sustituyen visualmente las conexiones lógicas, casuales, consecutivas, por asociaciones de tipo impresivo, metonímico o metafórico en el que el lector como co-enunciatario participa activa y rápidamente. De ahí que en su devenir, el discurso publicitario haya ido delegando la narración en el dominio de lo visual. Siguiendo con el ejemplo que nos ocupa, el anuncio de Veterano (fig. 4) puede representar todas y cada una de las características teóricas que hemos indicado arriba:

1) Existe una apropiación de valores, que se presenta gratuitamente pues, a diferencia de los relatos míticos, no existe una confrontación o combate directo con antihéroes en el espacio textual ${ }^{23}$, ni tampoco una competencia previa para el saber hacer del sujeto-marca. Se establece de este modo

${ }^{23}$ Creemos que esta confrontación que se produce en el orden comercial con otras marcas de un mismo tipo de producto, y que está en los albores de la publicidad como discurso económico. se han ido diluyendo a lo largo del tiempo para dejar en escena sólo el mensaje simbólico, que no compite más que consigo mismo. En la actualidad son muy escasos los enunciados explícitos de comparación o combate. 
un pacto pragmático entre el lector de anuncios y la obra publicitaria como obra de ficción ${ }^{24}$ sobre la que no solemos plantearnos cuestiones de adecuación respecto al mundo (v.g.: ¿cómo consigue la marca predicarse esos valores?). La prueba desvirtuada pero densa en significaciones consiste en que Veterano se predica a sí mismo una serie de valores hispánicos, asociados a la fiesta nacional y al toro que impregnan toda la cultura española:

- La corrida entendida como tragedia, un escenario de pasión, sol y sangre en el que se prueba la valentía (u hombría) del torero.

- La corrida asociada al folclore andaluz: las manolas, las letras de los pasodobles, la religiosidad popular de los toreros, el traje de luces.

- La denominación topológica de España como piel de toro.

- La gastronomía española que ofrece asimismo rabos de toro entre sus platos típicos y tapas.

- La literatura, la pintura y las artes, en general, desde el Guernica de Picasso hasta los Toros de Guisando del Lazarillo de Tormes.

- La interjección más genuina del léxico español: ¡olé!

La propia ganadería taurina de Osborne.

2) La fuerza de este anuncio estriba en su apuesta por una imagen, la de la corrida, más sugerente y expresiva de la españolidad que la enunciación verbal, pues enlaza significados ya asociados en la competencia del lector de imágenes hispánico ${ }^{25}$ y las vierte directamente en el nombre propio de la marca.

\subsection{La rigidez emotiva o la ausencia de pasión}

Si bien recogemos esta categoría de los magníficos estudios que desde la década de los ochenta se vienen produciendo en el entorno de la École de Paris (Hénault, 2002: 588-589, Fontanille, 2002: 601), que ya se averiguaban en el seno de las teorías peirceanas (Savan, 2002: 682-702) y que constituyen una nueva línea de estudios semióticos ${ }^{26}$, lo cierto es que la utilizamos como categoría genérica para referirnos a la emoción, a los sentimientos y a sus sensaciones,

\footnotetext{
${ }^{24}$ «La ficcionalidad es el estatuto de relación de la obra literaria con la realidad externa histórica o empírica suspendiéndose la exigencia de adecuación a la oposición verdadero/falso» (Pozuelo Yvancos, 1993: 63-144).

${ }^{25}$ Nos referimos, claro está, a las imágenes de los carteles taurinos.

26 «Más allá de las investigaciones sobre las pasiones, iniciadas en l'École des Hautes Etudes desde 1977, distintas contribuciones permitir percibir otros horizontes de la 'nueva' semiótica» (Hénault, 2002: 590).
} 
entendidas como un conjunto de manifestaciones «afectivas» que anidan en los fondos textuales que estudiamos. En los estudios arriba citados el grado de rigurosidad, en cuanto a la aplicación hermenéutica y discursiva, es de una precisión tan elevada que su operatividad, en el espacio reducido de articulo, ha de considerarse más que imposible, impropia. Por eso, en este apartado nos referiremos sólo a los «exponentes textuales» que muestren efectos pasionales discursivos, ya que estas formas se revelan como estabilizadas ${ }^{27}$ en códigos identificables y previsibles (Fontanille, 2002: 618). Estos códigos vienen representados, fundamentalmente, por los lexemas e iconemas pasionales, el ritmo, la perspectiva, la modalidad, los códigos somáticos y los figurativos. Tales códigos pueden representar una orientación para el análisis de las pasiones que ha ido desvelando históricamente el discurso publicitario, en cuanto que se ha ido descubriendo que la narración sin emoción no seduce. Pensar es también, sino sobre todo, un estado emocional. Y las perspectivas, modalidades, códigos figurativos o ritmos que entran en acción en un discurso determinado, están cargadas de una intencionalidad persuasiva, de manera que frecuentemente se habla de estos fenómenos como instrumentos retóricos (Moliné, 1999: 405) o modalidades pasionales (Sánchez Corral, 1997: 205). La seducción de los programas narrativos no sólo estriba en la táctica narrativa y los valores que propone, sino que se asienta fuertemente en la emoción con la que los expone y la que, a su vez, es capaz de generar.

En los anuncios de bebidas alcohólicas de estos años no se apuesta por la emoción, ya que el tipo de programas narrativos, según venimos viendo, está orientado a la presentación del producto para el posterior reconocimiento en el ámbito comercial. La marca es todavía un objeto sobre el que el sujeto-consumidor opina, manipula, usa o muestra sin más argumentación que la afirmación de su excelencia ${ }^{28}$. La escasa aparición de la figura humana en tales paisajes textuales y la falta de antropomorfización del sujeto-marca contribuyen, conjuntamente, a la ausencia de estados afectivos. Si bien es cierto que en este subconjunto del corpus se repiten expresiones linguísticas como las que aparecen en las figuras: deleite, felicidad, feliz, (sana) alegría, (vidas) felices, deleita, alegría o satisfacción.. Tales expresiones no se acompañan de imágenes que fortalezcan términos manidos en el discurso publicitario. Por el contrario, suelen desfilar un conjunto de actitudes hieráticas o sonrisas con una alta connotación publicitaria, revelando su aire de «pose».

\footnotetext{
${ }^{27}$ La dificultad hermenéutica de la emoción o la pasión discursiva es considerable, teniendo en cuenta que estamos tratando una problemática sensible, subjetiva y tensiva, que se ha desconsiderada en los estudios semíticos por su apariencia inasible, volcada en lo subjetivo, y por oponerse a la lógica de la acción en tanto que la perturba, la desvía : «Desde el punto de vista de la acción no es sino un efecto superficial, esto es, una perturbación, del orden de la excepción o del exceso ; en este sentido la pasión es 'lo irreductible' de la acción, y lo irreductible es, al límite y por definición, lo incognoscible» (Fontanille -Zilberberg, 1998: 223).

${ }^{28}$ Sin duda alguna, el adjetivo más repetido en la publicidad de estos años como hemos podido observar es el de «exquisito».
} 
Los modelos publicitarios aparecen en unas actitudes emocionales codificadas, lo que Eco llama iconogramas publicitarios (1989 [1968]: 257), enunciados icónicos que remiten a significados convencionales, aprendidos tras la lectura de varias y variadas producciones textuales publicitarias. Hemos de señalar que la falta de medios para un grafismo de calidad contribuye, en gran medida, a que se opte por el dibujo donde la presencia humana, cuando se da, no transmite la misma identificación para el lector que la generada por la fotografía ${ }^{29}$. Debemos resaltar, asimismo, la mayoritaria presencia femenina en los mismos como un indicador añadido de la objetualización estática frente a la subjetividad dinámica que requieren los sentimientos, todo lo cual nos lleva a concluir la falta de «estrategia» emocional en tales anuncios.

El ritmo, entendido como juego de contrastes, discontinuidades, repeticiones y silencios para producir determinadas emociones (sorpresa, alegría, humor, etc.) se utiliza aquí, sin embargo, para fomentar, por asociación o repetición, el recuerdo. Es por eso que este ritmo más que asociarse a la emoción, al espacio significativo afectivo, se desplaza al espacio cognitivo. De hecho, los ritmos de color y tipografía se utilizan como los únicos expositores plásticos de la presencia de la marca. Si observamos con atención todos los anuncios que componen esta categoría, veremos que la mayoría destacan la marca cromáticamente en rojo, y tipográficamente con un tamaño mayor. Esta opción perceptiva, tan recurrente en tantos y tantos anuncios, conduce a crear una forma de percepción de la marca que al repetirse anuncio tras anuncio queda automatizada y fijada como norma en todos ellos.

Licor 43, Veterano, Magno, Independencia, Carabela, Soberano pasean sus rojos logotipos en el panorama textual español de los cincuenta, demostrando que la seguridad perceptiva (y la posterior memorización) está por encima de las insondables rupturas estéticas.

[La publicidad debe] aceptar los códigos al uso. Observa las preferencias multitudinarias sobre el vocabulario estético, su sintaxis más admitida y sus paradigmas y los sigue fielmente. Es como un arte de segunda mano respecto al arte creador pero más seguro que éste porque incluye un sistema de regulación que es el éxito. Dado que la mayoría estadística de los negocios es de este signo, son de este tipo la mayoría de mensajes publicitarios. Ello implica un trabajo hecho siempre a posteriori. Sólo acepta morfologías ya experimentadas. Sólo lo que ya ha sido previamente aceptado por los consumidores (Cirici, 1972: 30).

En cuanto a la parte verbal se refiere, destacamos la rima o repetición fónica y el énfasis enunciativo como los únicos significantes afectivos de los cincuenta. La rima fácil o ripio más a menos ingenioso constituyen la base rítmica en el aspecto verbal ya que, a nuestro juicio, está influenciado por la forma de anunciarse en otros medios como el radiofónico.

${ }^{29}$ De hecho, el género pict rico es tan escaso en la publicidad actual que su presencia se percibe bajo un uso connotativo, generalmente de significado lúdico e infantil. 
Recréate cuando bebas, contemplando lo que bebes, Antes de beber, lo hueles, y después, lo paladeas...

¡Ya verás que feliz eres! (Jerez González Byass)

¡Agosto!

ya pronto, la uva será mosto.

Y el mosto a su vez,

se irá convirtiendo

en vino de Jerez. (Jerez González Byass)

Sabor que quita sinsabores (Anís la Praviana)

De sobremesa Anís la Cordobesa ( La cordobesa)

Estas estructuras con versos y rimas resultan familiares a la tradición poética clásica del romance ya que en su mayoría copian, con mayor o menor fortuna, el octosílabo asonante. De ahí que podamos aplicarles el término de «versoides» ${ }^{30}$ (Grunig, 1990: 178). En casi todas estas estructuras rítmicas descubrimos :
a) Segmentos (Versoides)
b) de tamaño constante
c) que en posición final
d) poseen un sonido idéntico
e) en el mismo lugar de acentuación

Tomemos como ejemplo el cuerpo textual del anuncio González Byass y el eslogan de Anís La Cordobesa:

Recréate cuando bebas,

- - - - II - - - (e-a) $4+48$

contemplando lo que bebes,

- - - - II - - - (e-e) 4+48

Antes de beber, lo hueles,

- - - - - II - - (e-e) $5+38$

y después, lo paladeas...

- - $11--\ldots-$ (e-a) $3+58$

¡Ya verás que feliz eres!

- $-11-\ldots-$ (e-e) $3+58$

3) Este término lo recogemos de Grunig: «Utilizaremos entonces el término 'versoide' para designar los segmentos que recuerdan de manera más o menos exacta al verso clásico que tiene ocho pies (o podríamos decir ocho microsegmentos)» (1990: 178). 
De sobremesa

$$
\begin{aligned}
& ----- \text { (e-a) } 5 \\
& \text { Anís la Cordobesa } \\
& --\|----(\text { e-a) } 2+57
\end{aligned}
$$

En ambas formas estróficas (una quintilla de rima asonante y un pareado) nos encontramos con las características descritas en los cinco apartados, ya que se trata de segmentos, octosílabos y pentasílabos, que al final de cada periodo reproducen un mismo ritmo silábico (e-e, e-a) recayendo la acentuación en la penúltima sílaba.

Otro aspecto destacable, aunque minoritario, es la exclamación como procedimiento retórico para atraer la atención:

El español no bebe ¡Saborea! (Licor 43)

$$
\text { ¿Veterano? Sí, señor ¡Veterano! (Veterano) }
$$

Nos interesa remarcar este procedimiento porque, pese a su discreta aparición en estos años, constituye la avanzadilla de recursos centrados en la expresión emotiva, que se desarrollará constituyendo la principal fuente de las tácticas publicitarias en las épocas venideras. Barthes afirmaba que la exclamación corresponde al rapto brusco de la palabra, a la afasia emotiva. Moliné (1999: 419) añade que es todo un estilo y, a veces, un vicio publicitario, pues supone una sacudida al espectador, una alerta, un «ifíjate en esto!».

Si la tipografía y el color se utilizaban retóricamente para la percepción de la marca, los ritmos verbales presentes en estas estructuras persiguen la memorización mediante el recurso clásico de la musicalidad poética. Las estrategias de estos años se centran, por tanto, en el concepto del recuerdo, entendiendo que la función del mismo es un almacenamiento de información, facilitada por la repetición de formas o significantes en los anuncios. Se espera que, de este modo, el consumidor asocie una información, respecto a un producto determinado y /o su uso; la memorice, gracias a los rimas ingeniosas y a las estrofas pegadizas; y las utilice en el momento decisivo de la compra. Tanto para la narración de atributos como para la memcrización de los mismos, así como la marca, los «creativos» se servían de elementos del lenguaje verbal, porque no se confiaba todavía en el potencial narrativo de la imagen, entre otras razones, porque no existía una audiencia educada publicitariamente (Leiss, Kline y Jhally, 1990: 208) para llevar a cabo estas tareas o compartirlas responsablemente con las palabras.

\section{3 Publicidad racional: calidad, cualidad y uso del producto}

Ya hemos analizado el modo en que las racionalidades de la acción y la pasión conciben el cambio en el discurso publicitario de los cincuenta. Nos resta 
ahora abordar el tipo de cognición que se plantea en los reclamos publicitarios para bebidas etílicas. Según lo que venimos detallando, resulta fácil admitir que la racionalidad cognitiva que prima es la informativa y que, en cada anuncio, se bombardea al lector con valores prácticos referidos a la información y uso del producto, si bien estos valores no se presentan en gran número - como ocurre con la publicidad de principios de siglo, por ejemplo - y además, están matizados por una serie de aspectos simbólicos (la alabanza de la españolidad): todo apunta a una futura publicidad mítica. Sin embargo, la incapacidad del producto para apropiarse de valores, concretamente de valores míticos y la escasa y débil presencia humana, puesto que las personas aparecen en escena como si estuvieran «congeladas« en el espacio-tiempo, invita a pensar que la racionalidad mítica es todavía una tendencia latente.

Esta década podría abarcar lo que Leiss, Kline y Jhally consideran como construcciones culturales de idolatría e iconología (ésta se da fundamentalmente en los anuncios de tabaco) en la que toda la comunicación se establece en torno al producto en cuanto objeto provisto de una calidad, unas cualidades y un uso. Si repasamos algunas afirmaciones de los anuncios podremos corroborarlo. La mayor parte de este anuncios se limita a presentar icónicamente al producto, o atribuirle una serie de valores más o menos complejos respondiendo su argumentación principal al cuándo y cómo de la consumición de lo anunciado, actividad publicitaria primaria y básica sobre la que muy pocos anuncios actuales se pronuncian $^{3 !}$.

Así, el Licor 43 repite en varios de sus anuncios «En bodas, bautizos, onomásticas, es invitado de honor el exquisito Licor 43. Pruebe usted, en desayunos y meriendas a hacer un PIM-BO. ¡Es tan fácil! En el café con leche, añada una copita de este finísimo licor. Le gustará y le alimentará». «Un grato momento cuando en estas Fiestas de Reyes se sirve la bebida ya tradicional en todos los hogares: el exquisito Licor 43». La consumición en fiestas la utiliza también Anís Salzillo: «Cuando tocan a fiestas...Anís Salzillo». Codorniu aconseja igualmente: «En las tertulias. Cuando reúna en casa a sus amigos, ofrézcales el regalo exquisito de unas copas de CODORNIU. Nada encanta tanto el diálogo y el ingenio como su rico sabor, su limpia transparencia y su finísima espuma...». La misma marca reiteraba esta idea en otro anuncio «Para brindis y junto al pastel de boda... En la espuma de la champaña CODORNIU, en el olor de tradición que expresa su calidad, en su sabor delicioso, hay un augurio de vidas felices. De forma parecida se publicita Calisay «Acompañe su lectura predilecta con una copa de Calisay» «Un licor exquisito a cualquier hora del día».

Muchos de estos anuncios pueden incluirse en esta fase de idolatría del producto, donde aún no se ha creado el signo, esto es, la marca, y donde los anuncios presentan una fuerte veneración hacia el objeto físico o el producto con estilo generalmente desapasionado y artificial.

\footnotetext{
"Siempre y cuando no se trate de un producto nuevo o relacionado con la tecnología.
} 
Tal estrategia »abierta « puede ser descrita como racional, puesto que su discurso está saturado de narratividad descriptiva sobre los productos y sus cualidades principales, acerca del amplio abanico de sus usos y beneficios potenciales, acerca de las sensatas ventajas para el ahorro de tiempo, energía y dinero, etc. En cierto modo, puede ser caracterizado como un discurso casi-lógico ya que la superficie textual - fría, informativa, razonada - se encarga de predicar diferencias vitales entre productos y usos muy similares, pero, sobre todo, de distinguirlos, apoyándose en el concepto de calidad, de los productos fraudulentos tan corrientes en el mercado negro de la época.

La insistencia en el concepto de tradición ( «Siempre bebí centenario»; «Como sus abuelos beba Calisay»; «Escat, aumenta de prestigio desde 1864»; «Marie Brizard, dos siglos de tradición»; «Desde 1870, Anís el Mono»; «Con estas copas y esta champaña ya brindaron nuestros abuelos. Codorniz», etc.) así como la notoria presencia concedida a la empresa y su ubicación - nos referimos a la destacada tipografía con la que ambos se anuncian - suponen una garantía de la continuidad consumista de un producto en la línea cronológica debido a su continuada demanda. Tal concepto de antiguiedad poco o nada tiene que ver con la actividad artesana individual de antaño. Es más, simboliza justamente todo lo contrario, a saber: su sustitución por la fabricación en serie y los primeros destellos de una organización de tipo capitalista. Como señala Boorstin (1973: 90) en el mundo antiguo casi todo lo que un hombre poseía era único en su tipo. En el nuevo mundo, los objetos únicos (excepto las joyas y las obras de arte) son una rareza y se convierten en sospechosos. Si un objeto de igual diseño y marca es ampliamente usado por otros muchos, esto se convierte en un seguro de validez.

La imagen de marca de un producto supone la predicación de su individualidad como signo y, por ende, como objeto de consumo. Todos los programas narrativos de la publicidad aspiran en la actualidad a la creación de la imagen de marca, que, en su estructura más profunda, supone una afirmación del valor propio de todo signo dentro de un sistema basado en la diferenciación. En estos primeros años del marketing, las agencias aún no habían valorado la posibilidad de centrarse en la identidad de la marca, esto es, no se trataba de ponderar y diferenciar signos, sino objetos a través de signos, de tal manera que, los programas estratégicos ligados a lâ referencialidad inmediata aparecen para el espectador de hoy como inverosímiles, exagerados o poco creíbles. En realidad, la diferencia de estos programas con los que se producen en la actualidad es que aquellos dejaban entrever su intencionalidad mercantil y su referente económico, mientras la publicidad de hoy tiene su propio universo de referencias a las cuales remite, que son de tipo simbólico, no mostrando en ningún caso las de tipo económico. Ya no tanto porque tal tarea sea contraproducente, sino porque resulta, a todas luces, inútil. En la actualidad, la publicidad es más que nunca un discurso que vende signos, mensajes, a los que se adhieren artificialmente los productos o servicios. 


\section{BIBLIOGRAFIA}

AA. VV. (2000): Símbolos de España, Madrid: Centro de Estudios Políticos y Constitucionales.

Alonso, Luis Enrique y CoNDE, Fernando (1994): Historia del consumo en España, Madrid: Debate.

Álvarez Junco, José (2001): Máter dolorosa. La idea de España en el siglo XIX, Madrid: Taurus.

ANCELOT, Sylvie (1997): Señas de hispanidad. Retrouver l'Espagne: clichés, mythes, repères..., París: Ellipses.

Barthes, Roland (1957): Mythologies, París: Seuil (trad. cast.: Mitologías, Madrid: Siglo XXI, 1980).

BARTHES , Roland (1964): "Rhétorique de l'image» en Communications, 4.

BARTHES , Roland (1970a): Elementos de la semiología, Madrid: Alberto Corazón [1965].

BARTHEs, Roland (1986): Lo obvio y lo obtuso. Imágenes, gestos, voces, Barcelona: Paidós [1982].

BoORstin, Daniel J (1973): The Americans: The Democratic Experience, Nueva York: Random House.

Christin, Anne-Marie (2001): L'image écrite ou la déraison graphique, París: Flammarion [1995].

Cirici, Alexandre (1972): «Publicidad y estética» en Control de publicidad y medios, enero.

CIRICl , Alexandre(1977): La estética del franquismo, Barcelona: Gustavo Gili.

Dumkzil, Georges (1968): Mythe et epopee I, París: Gallimard.

DYer, William (1982): Advertising as Communication, Londres: Metheun.

Eco, Umberto (1989): La estructura ausente. Introducción a al semiótica, Barcelona: Lumen (4a ed.) [1968].

FloCH, Jean Marie (1993): Semiótica, marketing y comunicación. Bajo los signos las estrategias, Barcelona: Paidós [1991].

FLOCH , Jean Marie (1995): Identités visuelles, París: PUF.FONTANILLE, Jacques (1982) : Un point de vue sur croire et savoir : les deux systèmes de l'adéquation cognitive, Actes sémiotiques, pp. 5-31.

FONTANILle, Jacques (1998): Sémiotique du discours, Limoges: Pulim.

Fontanille , Jacques; Zilberberg, Claude (1998): Tension et signification, París: Mardaga

Fontanille , Jacques (ed.) (1999): Métiers de la sémiotique, Limoges: Pulim.

GeNINASCA, Jacques (1997): La parole littéraire, París: PUF.

Greimas, Algirdas Julien (1983): Du Sens Il. Essais sémiotiques, París: Éditions du Seuil.

GreIMAS , Algirdas Julien (1989): Del sentido II, Madrid: Gredos.

Greimas, Algirdas Julien y FONTANILLE, Jacques (1994): Semiótica de las pasiones. De los estados de cosas a los estados de ánimo, México: Siglo XXI [1991].

Gruning, Blanche (1990): Les mots de la publicité, París: Presses du CNRS.

Hénault, Anne (1997): Histoire de la sémiotique, Paris, Que sais-je? [1992].

JAKOBSON, Roman (1975): Ensayos de Lingüística General, Madrid, Seix Barral.

LEISS, William; KLINE, Stephen; JHALLY, Sut (1997): Social Communication in Advertising, ( $2^{\mathrm{a}}$ ed., revisada y aumentada), Londres y Nueva York: Routledge [1990]. 
Lévi-Strauss, Claude (1958): Anthropologie structurale, París: Plon (1985).

LANDOWSKi, Éric (1997): Présences de l'autre, París: PUF.

LÓPEZ GARCía, Ángel (1989): Fundamentos de lingüística perceptiva, Madrid: Gredos

MARTínez Tórtola, E. (1996): La enseñanza de la historia en el primer bachillerato franquista (1938-1953), Madrid: Tecnos.

MUKAROVSKY, Jan (1942): «The place of aesthetic function among the other functions» en Structure, Sign and Function, New Haven: Yale, Univ. Press, pp. 31 -48.

NöTH, Winfried (1995): Handbook of Semiotics, Bloomington: Indiana University Press.

Núnez Florencio, Rafael (2001): Sol y Sangre. La imagen de España en el Mundo, Madrid: Espasa-Calpe.

PANIER, Louis (2000): Comptes rendues critiques. Jacques Fontanille: Sémiotique du discours « en Nouveaux actes sémiotiques, 68-69-70, pp. 73-87.

PARRET, Herman (1982a): "Eléments pour une typologie raisonnée des passions» en Actes sémiotiques: Documents IV, 37, pp. 5-29.

Parret , Herman (1982b): «Pour une sémiotique du discours passionnel» en Proceedings of the Second International Congress of the International Association of Semiotics Studies (Viena, 1979).

PARRET , Herman (1997) «Greimas and his school» en Thomas SEBEOK, (ed.): Semiotik / Semiotics. Ein Handbuch zu den zeichentheorischen Grundlagen von Nature und Kultur / A handbook on the Sign-Theoretic Foundations of Nature and Culture, vol. I, Berlín, Nueva York: Walter de Gruyter.

Pascal, Blaise: Pensées, París: LGF [1660], 2003 (trad. cast.: Pensamientos, Madrid: Alianza, 1980).

PÉNInOU, Georges (1972): Intelligence de la publicité: étude sémiotique, París: Robert Laffont.

Pozuelo Yvancos, José Maria (1993): Poética de la ficción, Madrid: Síntesis.

Prope, Vladimir Jakovlevic (1977): Morfología del cuento, Madrid: Fundamentos [1928].

Pérez Tornero, José Manuel (1982): La Semiótica de la publicidad. Análisis del lenguaje publicitario, Mitre: Barcelona.

Ricoevr, Paul (1986): Du texte à l'action. Essais d'herméneutique II, París: Ed. du Seuil (trad. cast.: Del texto a la acción. Ensayos de hermenéutica II, Buenos Aires: Fondo de Cultura Económica, 2001)

RuANO-BORBOlan, Jean-Claude (ed.) (1998): L'identité. (L'individu. Le groupe. La société), París: Sciences Humaines

Ruiz TORREs, Pedro (2001): «Les usages politiques de l'histoire de l'Espagne. Formes, limites et contradictions» « en François Hartog y Jacques Revel (eds.), Les Usages politiques du passé, París: EHESS.

SÁnCHEZ CORRAL, Luis (1997): Semiótica de la publicidad. Narración y discurso, Madrid: Síntesis.

SutIL Martín, Dolores Lucía (1991): Mensajes subliminales en la publicidad, Madrid: Servicio de publicaciones de la Universidad Complutense.

Tranche, Rafael; SÁNCHEZ BIOSCA, V. (2001): NO-DO. El tiempo y la memoria, Madrid: Cátedra, Filmoteca Española.

VICTOROFF, David (1972): „Nouvelle voie d'accès à l'étude de l'image publicitaire: l'analyse sémiologique Bulletin de psychologie 25, pp. 521-532.

ZILBERBEG, Claude (1981): Essai sur les modalités tensives, Ámsterdam: John Benjamins. 